\title{
Some Properties of a Bacterial Protease with a Specific Effect on the Protein in Tobacco Rattle Virus Particles
}

\author{
By M. A. MAYO, D. J. ROBINSON AND M. C. M. PÉROMBELON \\ Scottish Horticultural Research Institute, Invergowrie, Dundee
}

(Received 25 February 1974; revised 23 May 1974)

\begin{abstract}
SUMMARY
A pseudomonad bacterium contaminating a preparation of purified tobacco rattle virus was isolated. It produced proteolytic enzyme activity in nutrient broth + I $\%$ glucose; activity was greatest in the stationary phase of growth. This enzyme acted on the protein in particles of tobacco rattle virus to produce a polypeptide that migrated more rapidly in sodium dodecyl sulphate-acrylamide gels than untreated virus coat protein. The estimate of molecular weight of the modified protein was less affected by gel strength than that of the unmodified protein. The enzyme appeared as a single component when analysed by polyacrylamide gel electrophoresis or by gel filtration in Sephadex G-IOO; its apparent molecular weight was about 45000 . Enzyme activity did not require added thiol reagents, but was reversibly inhibited by EDTA.
\end{abstract}

\section{INTRODUCTION}

When preparations of tobacco rattle virus (TRV:R/I:2.5/5+0.7/5:E/E:S/Ne) were stored at $4{ }^{\circ} \mathrm{C}$ in the absence of antimicrobial agents the coat protein of the virus was apparently partially degraded, and it was suggested that a bacterial extracellular enzyme was causing proteolysis (Mayo \& Cooper, 1973). The effect of the presumed enzyme was to decrease the apparent molecular weight of the protein by about 5000. However, these estimates of molecular weights were made using electrophoresis in polyacrylamide gels containing sodium dodecyl sulphate, and recent studies on TRV protein (Ghabrial \& Lister, I973) suggest that the estimates may have been incorrect. Whatever the interpretation, the electrophoretic mobility in polyacrylamide gels of the virus polypeptide-dodecyl sulphate complex was increased. Papain caused a similar but not identical change in the protein of TRV particles, whereas trypsin or chymotrypsin had no effect (Mayo \& Cooper, 1973). However, in contrast with that of papain, the activity of the presumed enzyme was stable for long periods in solution at $4{ }^{\circ} \mathrm{C}$. We have now isolated and partially characterized the bacterium producing the protease responsible, and have determined some properties of the enzyme.

\section{METHODS}

Virus. The CAM strain of tobacco rattle virus (Harrison \& Woods, I966) or a single lesion isolate derived from it were used throughout. Virus was purified from systemically infected leaves of Nicotiana clevelandii Gray by differential centrifugation (Cooper \& Mayo, 1972). Preparations were stored at $4{ }^{\circ} \mathrm{C}$ in $0.017 \mathrm{M}$-phosphate buffer $\mathrm{pH} 7$, containing $0.02 \%$ sodium azide.

Culture and identification of bacterial isolate P179. Stock cultures of the isolate were maintained on nutrient agar (Oxoid $\left.\mathrm{CM}_{3}\right)$ at $5{ }^{\circ} \mathrm{C}$. Inocula for liquid cultures were prepared by 


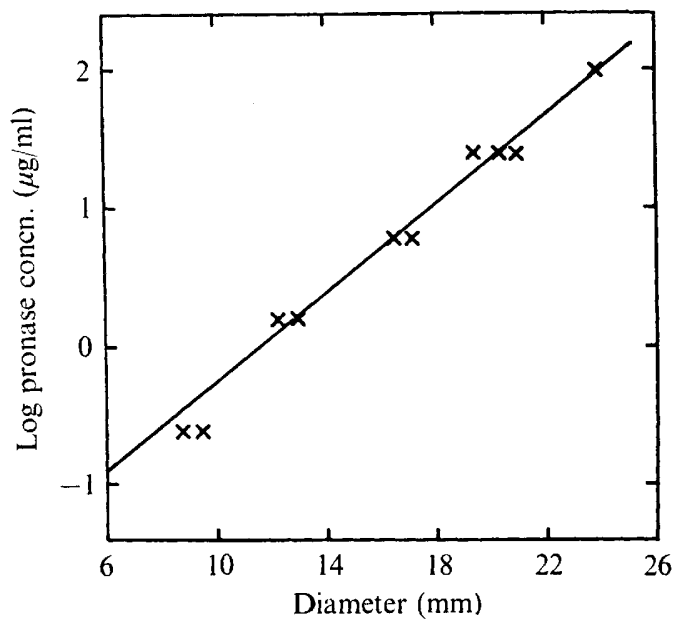

Fig. I. Relationship between logarithm of pronase concentration and the diameter of the zone of precipitation formed in caseinate-agar plates. Enzyme solutions were placed in $6 \mathrm{~mm}$ diam wells and plates were incubated at $37^{\circ} \mathrm{C}$ for $19 \mathrm{~h}$. The plotted regression line was calculated excluding the results obtained with the smallest concentration of enzyme.

growing subcultures on slopes of nutrient agar at $27{ }^{\circ} \mathrm{C}$ for $48 \mathrm{~h}$. The position of flagella was determined by electron microscopy, and the production of acid from carbohydrates was assessed in Dowson's inorganic basal medium (Graham \& Hodgkiss, 1967). Other tests were as described by Cowan \& Steel (I965).

Assay for proteolytic enzyme. Proteolytic activity was determined using the casein precipitation reaction (Sandvik, I963; Fossum, I970). Test solutions were used to fill $6 \mathrm{~mm}$ diam wells cut in plates of $\mathrm{I} \cdot 4 \%$ agar containing $\mathrm{I} \%$ sodium caseinate (Kodak) pH 6.2, $0.004 \mathrm{M}-$ magnesium chloride and 0.01\% sodium azide (Sandvik, I963). After incubation for I8 $\mathrm{h}$ at $37{ }^{\circ} \mathrm{C}$, the diameters of the zones of precipitation formed around the wells were measured and compared with the diameters of zones formed by solutions of pronase (Calbiochem B grade, 45000 units $/ g$ ). The zone diameter was linearly related to the logarithm of pronase concentration except at very low concentrations (Fig. I), and the limit of detection was about $0 . \mathrm{I} \mu \mathrm{g}$ pronase $/ \mathrm{ml}$. A similar plot of the effect on zone diameter of diluting the bacterial enzyme produced a straight line parallel with that shown in Fig. I. Enzyme activity was expressed in arbitrary units, defined so that the concentration in units/ml was numerically equal to the concentration of pronase in $\mu \mathrm{g} / \mathrm{ml}$ that would give a precipitation zone of the same diameter.

Sephadex gel chromatography. A culture in nutrient broth (Oxoid CMI) + I \% glucose was incubated for 2 days at $27^{\circ} \mathrm{C}$, and $40 \mathrm{ml}$ of the supernatant fluid remaining after removing bacteria by centrifugation was made $70 \%$ saturated in ammonium sulphate. The precipitated protein, which included protease, was dissolved in $2 \mathrm{ml} 0.02 \mathrm{M}$-tris- $\mathrm{HCl}+0.05 \%$ sodium azide, $\mathrm{pH} 7.2$, and samples of I $\mathrm{ml}$ were eluted at about $0.6 \mathrm{ml} / \mathrm{min}$ from a $42 \times \mathrm{I} .6 \mathrm{~cm}$ column of Sephadex G-100. Fractions of the effluent were collected at 2.5 min intervals, their absorbances at $280 \mathrm{~nm}$ were measured, and a sample of each fraction was tested for proteolytic activity. The volume required for elution of enzyme activity was compared with those for blue dextran 2000 (Pharmacia), ovalbumin and $\alpha$-chymotrypsinogen A (Sigma).

Electrophoresis in polyacrylamide gels. Virus protein samples were prepared for electrophoresis in polyacrylamide gels containing sodium dodecyl sulphate (SDS) by heating samples $(\mathrm{I} \mathrm{mg} / \mathrm{ml})$ in $0.0 \mathrm{I}$ M-sodium phosphate $\mathrm{pH} 7$, containing I $\% \mathrm{SDS}+0 . \mathrm{I} \%$ dithio- 
Table I. Physiological characteristics of isolate PI 79

\begin{tabular}{lc}
\multicolumn{1}{c}{ Test } & Result \\
Oxidase & + \\
Oxidation/fermentation & Oxidative \\
Acid production from & \\
$\quad$ Glucose & $(+)$ \\
Fructose & $(+)$ \\
Lactose & - \\
Maltose & - \\
Sucrose & - \\
Rhamnose & - \\
Mannitol & - \\
Sorbitol & - \\
Glycerol & - \\
2-Ketogluconic acid & \\
Hydrolysis of & + \\
Gelatin & - \\
Starch & - \\
Arginine & - \\
Reduction of nitrate & \\
Production of & - \\
Indole & - \\
Hydrogen sulphide & - \\
Levan & AP \\
Litmus milk & \\
Growth at $37^{\circ} \mathrm{C}$ & - \\
Growth at $42^{\circ} \mathrm{C}$ & - \\
Production of fluorescent pigment on King's B medium & - \\
\end{tabular}

+ , Positive reaction; $(+)$, reaction occurring after 7 days' culture; - , no reaction; AP, acid reaction followed by complete peptonization.

threitol, in a boiling water bath for $90 \mathrm{~s}$. Electrophoresis was for about $5 \mathrm{~h}$ in $10 \%(\mathrm{w} / \mathrm{v})$ polyacrylamide gels containing $0 . \mathrm{I} \% \mathrm{SDS}$ and $0 . \mathrm{I}$ M-sodium phosphate $\mathrm{pH} 7$ (Mayo \& Cooper, 1973), using a slab-type apparatus (Universal Scientific Ltd). Bands of protein were located by staining the gels with $0.25 \%$ Coomassie blue in methanol-water-acetic acid (5:5: I, by volume). Molecular weights were estimated by comparing the mobilities of bands of virus protein with the mobilities of proteins of known molecular weight (Mayo \& Cooper, 1973).

Enzyme preparations were analysed by electrophoresis in $0.01 \mathrm{M}$-tris-glycine buffer, $\mathrm{pH} 8.9$, in $7.5 \%$ (w/v) acrylamide gels as described by Winters \& Corpe (I97I). Crude enzyme was prepared as described for gel filtration experiments. Precipitated enzyme was dialysed against $0.05 \mathrm{M}$-ammonium acetate $\mathrm{pH} 7$, freeze-dried, and then dissolved in a small volume of 0.01 M-tris-glycine $\mathrm{pH} \mathrm{8.9}$. Electrophoresis was for $\mathrm{I} h$ at $3 \mathrm{~mA}$ per $4 \times 8 \mathrm{~mm}$ cross-section gel. Enzyme was located in the gels by testing eluates of slices using caseinate plates, and bands of protein were located by staining with Coomassie blue (as above).

\section{RESULTS}

Isolation of enzyme-producing bacterium

A purified preparation of tobacco rattle virus (CAM) which had been kept for several months at $4{ }^{\circ} \mathrm{C}$ without antibacterial agents was diluted with sterile water and spread on 


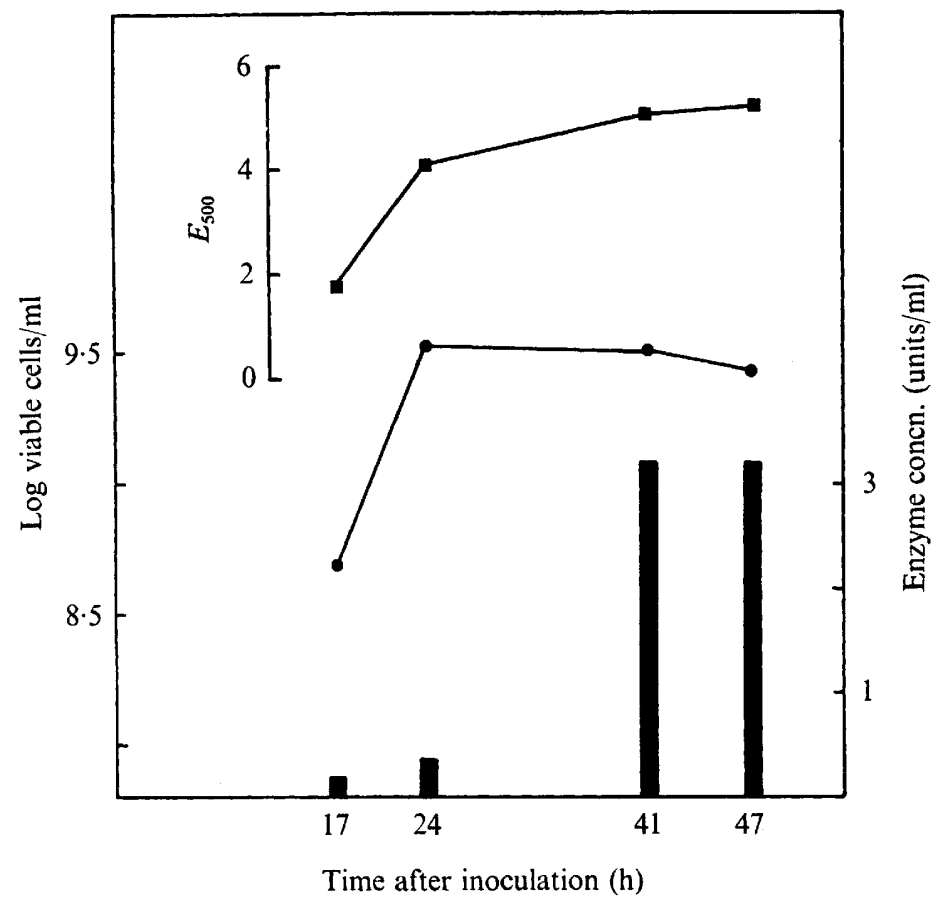

Fig. 2. The production of protease by isolate PI 79 during growth. Flasks containing Io ml nutrient broth $+\mathrm{I} \%$ glucose were inoculated with $10^{8}$ bacteria and shaken at $25{ }^{\circ} \mathrm{C}$. The concentration of viable cells (O), the turbidity ( $\mathbf{a})$ and the enzyme activity (vertical bars) were determined at intervals.

nutrient agar. Most of the colonies formed were either white or yellow. Only bacteria from the yellow colonies produced proteolytic enzyme when cultured, and an isolate from one of these colonies, designated PI79, was deposited with the National Collection of Industrial Bacteria, Torry Research Station, Aberdeen, as NCIBI0939. When bacteria were centrifuged from cultures in a basal salts medium $\left(0.5 \%\right.$ glucose, $0.1 \% \mathrm{NH}_{4} \mathrm{H}_{2} \mathrm{PO}_{4}, 0.02 \% \mathrm{KCl}$ and $0.02 \% \mathrm{MgSO}_{4} \cdot 7 \mathrm{H}_{2} \mathrm{O}, \mathrm{pH} 7.2$ ) after growth for 4 days at $25{ }^{\circ} \mathrm{C}$, the supernatant fluid partially degraded the coat protein of freshly purified CAM particles.

\section{Properties of isolate PI 79}

The bacteria are short Gram-negative rods with one to several polar flagella. Growth on nutrient agar was sparse, and colonies appeared pale yellow and slimy. The results of physiological tests are summarized in Table I.

\section{Production of crude enzyme}

Flask cultures in nutrient broth $+\mathrm{I} \%$ glucose were sampled at different times after inoculation. Culture turbidities were measured as the absorbance of samples at $500 \mathrm{~nm}$ in I cm pathlength cells. Concentrations of viable cells were estimated as described by Pérombelon \& Lowe (197I), and enzyme activities in the supernatant fluids remaining after removing the bacteria by centrifugation were determined (Fig. 2). The enzyme concentrations in culture fluids sampled during the stationary phase were much higher than those in cultures in the exponential phase of growth. Neither the turbidity of the cultures nor the 


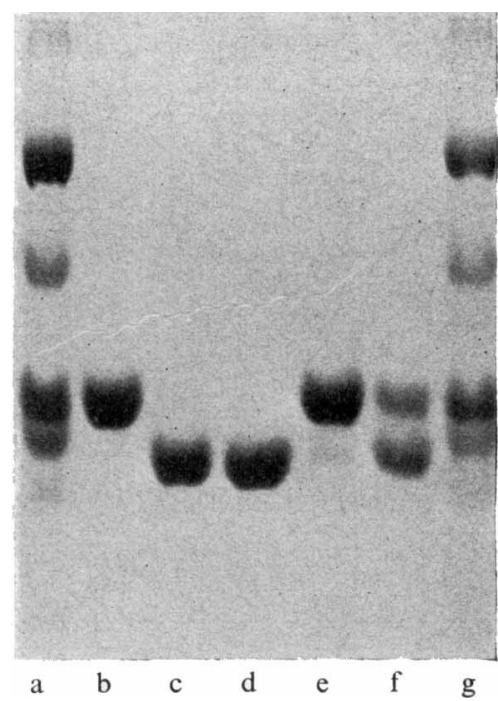

Fig. 3. Electrophoresis of tobacco rattle virus protein in acrylamide gels containing sodium dodecyl sulphate, showing the effect of inhibitors on the action of bacterial protease on protein in virus particles. Electrophoresis was for $5 \mathrm{~h}$ at $5 \mathrm{~V} / \mathrm{cm}$ in $10 \%$ acrylamide gels. (a) and (g) Calibration mixture of proteins; bovine serum albumin, ovalbumin, carbonic anhydrase and $\alpha$-chymotrypsinogen A. (b) Protein from virus incubated for $24 \mathrm{~h}$ at $30^{\circ} \mathrm{C}$ without enzyme. (c) Protein from virus incubated as in (b), but with enzyme. (d) Protein from virus incubated as in (c) but with enzyme mixed with 0.01 M-iodoacetamide I h before incubation. (e) As (c), but enzyme pretreated for $\mathrm{I} h$ with o.or M-EDTA. (f) As (c), but enzyme pretreated for I h with o.or M-dithiothreitol.

viable counts (Fig. 2) gave any indication of cell lysis; but to designate this enzyme as extracellular would not be justified without further investigation.

\section{Stability of enzyme preparations}

In crude preparations the protease was remarkably stable. Activity in such preparations was not diminished by freezing to $-20^{\circ} \mathrm{C}$ several times, or by storing at $25^{\circ} \mathrm{C}$ for 3 days. When stored at $4{ }^{\circ} \mathrm{C}$ the activity of a preparation scarcely changed in 7 days and had decreased to about one-third the initial value after 26 days. When preparations were heated for $10 \mathrm{~min}$ in $0.02 \mathrm{M}$-tris- $\mathrm{HCl}+0.05 \%$ sodium azide, $\mathrm{pH} 7.2$, activity was largely unaffected at $55^{\circ} \mathrm{C}$, decreased by about half at $65{ }^{\circ} \mathrm{C}$ and only a trace of activity survived heating at $70{ }^{\circ} \mathrm{C}$.

\section{Effect of EDTA, dithiothreitol and iodoacetamide on enzyme activity}

Caseinate-agar plates could not be used for testing the effect of chelating agents, so treated and untreated samples of enzyme preparations were compared using their ability to convert the protein in CAM particles to a faster-migrating electrophoretic form. An enzyme preparation was dialysed against $0.0 \mathrm{I} \mathrm{M}$-sodium phosphate $\mathrm{pH} 7 \cdot 0$, containing $0.02 \%$ sodium azide. Samples $(0.1 \mathrm{ml})$ were incubated with $0.0 \mathrm{I} \mathrm{M-EDTA,} \mathrm{0.0} \mathrm{I} \mathrm{M-dithiothreitol} \mathrm{or} \mathrm{0.0} \mathrm{I} \mathrm{M-iodo-}$ acetamide for $\mathrm{I} \mathrm{h}$ at $30{ }^{\circ} \mathrm{C}$ and $0.2 \mathrm{mg}$ CAM in $0.02 \mathrm{ml}$ was added. After $24 \mathrm{~h}$ at $30^{\circ} \mathrm{C}$ the samples were heated with sodium dodecyl sulphate and analysed by electrophoresis in $10 \%$ (w/v) acrylamide gel. Enzyme activity was unaffected by iodoacetamide, about $40 \%$ inhibited by treatment with dithiothreitol, and was inhibited almost completely by EDTA (Fig. 3). When a preparation was incubated with $0 \cdot 0 \mathrm{I}$ M-EDTA for $\mathrm{I} h$ and then dialysed to remove the EDTA, the enzyme activity was fully restored showing that the inhibition was 


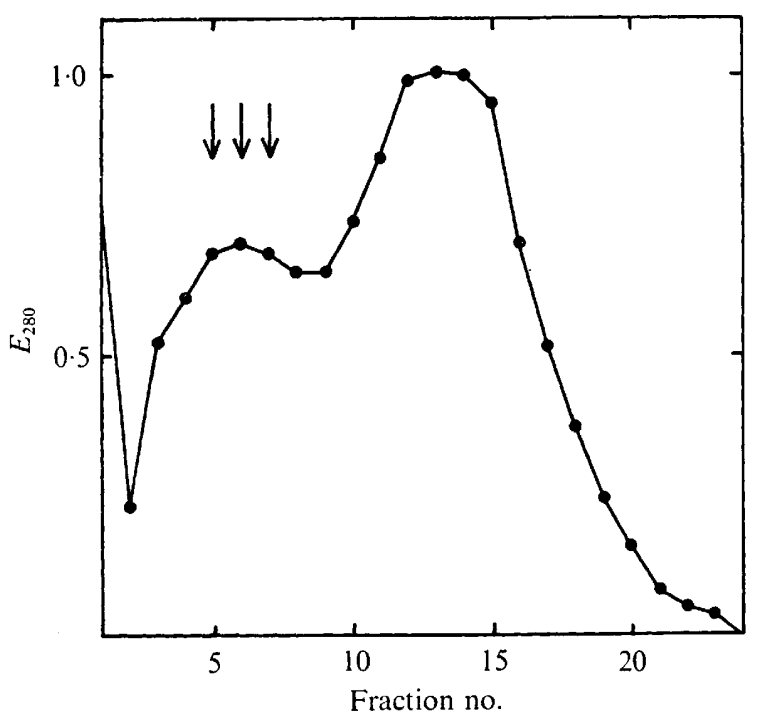

Fig. 4. Chromatography in Sephadex G-100. A calibration sample containing blue dextran, $10 \mathrm{mg}$ ovalbumin and $10 \mathrm{mg} \alpha$-chymotrypsinogen $A$ in I ml was applied to a column $(42 \times \mathrm{I} \cdot 6 \mathrm{~cm}) \mathrm{of}$ Sephadex G-100 and the absorbances of fractions collected every 2.5 min were measured in I cm pathlength cells using a Unicam SP 500 spectrophotometer $(\odot)$. In a separate experiment, I ml enzyme preparation mixed with blue dextran was applied to the same column and $2.5 \mathrm{~min}$ fractions were collected at the same flow rate. The elution volumes of the blue dextran in the two experiments coincided and were designated fraction $I$. The fractions from the second experiment which contained most enzyme activity are indicated by arrows.

reversible. Inhibition by EDTA suggests that a divalent metal cation is essential for enzyme activity. The partial inhibition with dithiothreitol may also be caused by a chelation effect, although in another experiment inhibition by $0.007 \mathrm{M}$-dithiothreitol was unaffected by the presence of 0.013 M-magnesium chloride.

\section{Gel chromatography in Sephadex columns}

Enzyme activity was eluted as a single peak from columns of Sephadex G-I0o in approximately the same volume as was ovalbumin (Fig. 4), suggesting that the molecular weight of the enzyme is about 45000 .

\section{Electrophoresis in polyacrylamide gel}

Two enzyme preparations were examined. A bacterial culture in nutrient broth $+\mathrm{r} \%$ glucose was centrifuged after $48 \mathrm{~h}$ at $27{ }^{\circ} \mathrm{C}$. The supernatant fluid $(2 \mathrm{ml})$ was used as one enzyme preparation (S) and the pellet of bacteria was suspended in $2 \mathrm{ml}$ sterile phosphate buffer and kept for 4 days at $27^{\circ} \mathrm{C}$. The supernatant fluid obtained by centrifuging this suspension was used as the other enzyme preparation $(\mathrm{L})$. The enzyme activities were 3 units/ $\mathrm{ml}(\mathrm{S})$ and 0.5 units $/ \mathrm{ml}(\mathrm{L})$. The preparations were concentrated and each was applied to two acrylamide gels. After electrophoresis for $\mathrm{I} h$, one gel of each preparation was stained with Coomassie blue and the other was cut into $2 \mathrm{~mm}$ slices. The slices were eluted with $0.2 \mathrm{ml} 0.0 \mathrm{r}$ M-sodium acetate $\mathrm{pH} 6$ for 3 days at $4{ }^{\circ} \mathrm{C}$ and the eluates tested for enzyme activity in caseinate-agar plates (Fig. 5). Enzyme activity was recovered from two adjacent slices of a gel containing preparation $\mathrm{S}$ but no protein was detected by staining. In contrast, although bands of protein were detected in a gel of preparation $\mathrm{L}$, no activity was detected 


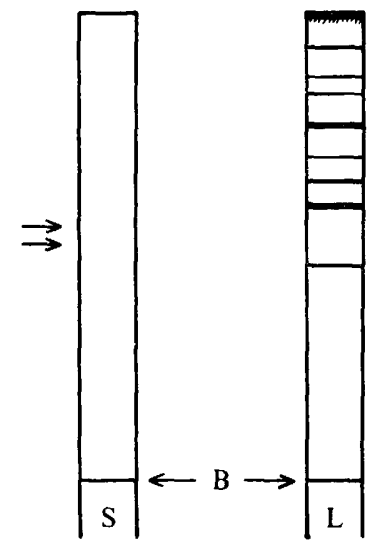

Fig. 5. Diagram of acrylamide gels stained with Coomassie blue after parallel electrophoresis of enzyme preparations S (gel S) and L (gel L). B indicates the position of the band of bromophenol blue included in the samples. Arrows indicate the positions of slices of gel from which proteolytic enzyme activity was eluted.

Table 2. Estimates of molecular weights of protein from tobacco rattle virus particles (strain $C A M$ ) using different strengths of acrylamide gel

Estimated mol.wt, using acrylamide strengths of $(\%)$ :

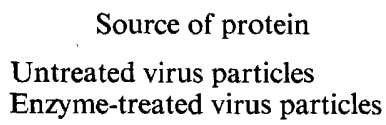

$\begin{array}{cccc}6 & 7 \cdot 5 & 8 \cdot 5 & 10 \cdot 5 \\ 33100 & 30400 & 29900 & 28200 \\ 25000 & 24000 & 23600 & 22800\end{array}$

in eluates of gel slices, presumably because less enzyme activity was loaded on these gels. The electrophoretic mobility of the enzyme in gel $\mathrm{S}$ did not coincide with that of any of the proteins detected in gel $\mathrm{L}$.

When incubated with purified CAM particles for 3 days at $30{ }^{\circ} \mathrm{C}$ eluates from slices of gel $\mathrm{S}$ which contained protease converted CAM protein to a faster-migrating electrophoretic form, whereas eluates from other slices were without effect on CAM protein.

\section{Effect on CAM protein}

The effect of PI79 protease on intact CAM particles is to increase the electrophoretic mobility of the coat protein in acrylamide gels containing sodium dodecyl sulphate. The electrophoretic mobility of most proteins in such gels is a function of the protein molecular weight, and estimates of molecular weight are usually not related to the strength of acrylamide gel used. However, Ghabrial \& Lister (1973) have shown that estimates of the molecular weights of proteins from some strains of tobacco rattle virus are affected by the gel strength used. Estimates of the molecular weight of protein from PI 79 protease-treated or untreated CAM particles were made by comparison with the migrations of marker proteins known to be unaffected by the strength of acrylamide gel used (Dunker \& Rueckert, I969) (Table 2). The estimates of the molecular weight of protein from untreated CAM particles were affected by gel strength, whereas those of protein from enzyme-treated CAM particles were only slightly affected. 


\section{DISCUSSION}

The physiological tests (Table I) suggest that the bacterial isolate PI79 probably belongs to the family Pseudomonadaceae. Using the key given in Bergey's Manual (1957), it is most similar, but not identical, to organisms grouped in the addendum to the genus Xanthomonas, group 2. These bacteria are yellow polar-flagellate species isolated from leaf surfaces or soil, and are probably not pathogenic to plants and thus not typical of the genus Xanthomonas.

The proteolytic enzyme produced by cultures of this bacterium does not require the presence of thiol reagents for activity, is active at $\mathrm{pH} 7$ and is inhibited by EDTA. Matsubara \& Feder (I97I) have attempted to classify microbial proteases into four groups, mainly using the effect of inhibitors on enzyme activity. The observations reported here suggest that PI79 protease should be classed with metal chelator-sensitive neutral proteases. This group, which includes proteases produced by Pseudomonas aeruginosa, requires a hydrophobic side-chain on the amino acid donating the amino group of the peptide bond cleaved. The PI79 enzyme is reversibly inhibited by EDTA as is one of the proteases from P. aeruginosa. However, other enzymes in this group are irreversibly inhibited (Matsubara \& Feder, 1971).

Gel chromatography and polyacrylamide gel electrophoresis showed that the proteolytic activity in crude preparations is largely if not entirely that of one enzyme. This contrasts with the results of Winters \& Corpe (I97I) who found four extracellular proteases in cultures of Pseudomonas fuorescens. Furthermore, gel chromatography suggests a molecular weight of about 45000 for the enzyme, which compares with an estimate of 48400 for the nonelastolytic protease from $P$. aeruginosa, which is a neutral protease reversibly inhibited by EDTA (Inoue, Nakagawa \& Morihara, 1963).

Partially purified preparations of PI 79 protease act on CAM particles to induce a change in the electrophoretic mobility of the coat protein and alter the effect of gel strength on estimates of the protein molecular weight. This is clearly the basis of the partial degradation during storage described by Mayo \& Cooper (1973). They reported that CAM particles were unaffected by treatment with trypsin or chymotrypsin, and that the limited degradation by PI 79 protease or papain did not significantly alter their infectivity. In this respect TRV resembles tobacco mosaic virus, the infectivity of which is not decreased by treatment with proteolytic enzymes such as trypsin, pepsin or papain (Stanley, 1934; Bawden \& Pirie, 1937). Potato virus $\mathrm{X}$, on the other hand, is readily attacked, and its infectivity destroyed by these enzymes (Bawden \& Pirie, 1936).

The changes in CAM protein are presumably related to the cleavage of at least one peptide bond. The limited nature of the proteolysis by both PI 79 protease and papain may be the result either of specificity for a particular peptide bond in the virus protein, or of the folding of the polypeptide in the virus particle, or a combination of both factors. It is not known what, if any, bond specificity the PI79 enzyme shows, although its grouping with other microbial proteases makes some specificity a possibility. Further work on the specificity of this enzyme would necessitate large-scale culture of the organism and purification steps additional to those used in this work. However, the properties we report, in particular the stability in solution, suggest that the enzyme could be further purified without difficulty.

We thank Mrs Agnes Donald and J. H. Raschké for valuable technical assistance. 


\section{REFERENCES}

Bawden, F. C. \& Pirie, N. W. (I936). Experiments on the chemical behaviour of potato virus X. British Journal of Experimental Pathology r7, 64-74.

BAwden, F. C. \& PIRIE, N. W. (I937). The isolation and some properties of liquid crystalline substances from solanaceous plants infected with three strains of tobacco mosaic virus. Proceedings of the Royal Society B I23, 274-320.

Bergey's Manual of Determinative Bacteriology, 7th edn (1957). Edited by R. S. Breed, E. G. D. Murray and N. R. Smith. Baltimore: Williams \& Wilkins.

COOPER, J. I. \& MAYo, M. A. (1972). Some properties of the particles of three tobravirus isolates. Journal of General Virology 16, 285-297.

CowAN, S. T. \& STEEL, K. J. (I965). Manual for the Identification of Medical Bacteria. Cambridge University Press.

Dunker, A. K. \& Rueckert, R. R. (I969). Observations on molecular weight determinations on polyacrylamide gel. Journal of Biological Chemistry 244, 5074-5080.

Fossum, K. (1970). Proteolytic enzymes and biological inhibitors. I. Comparison between the Kunitz method and the agar gel casein precipitating reaction for determination of the activity of some commercial proteolytic enzymes and inhibitors. Acta pathologica microbiologica scandinavica B 78, 350-362.

Ghabrial, S. A. \& Lister, R. M. (1973). Anomalies in molecular weight determinations of tobacco rattle virus protein by SDS-polyacrylamide gel electrophoresis. Virology 5I, 485-488.

Graham, D. C. \& HodGkiss, W. (1967). Identity of Gram-negative, yellow pigmented, fermentative bacteria isolated from plants and animals. Journal of Applied Bacteriology 30, 175-189.

HaRrison, B. D. \& Woods, R. D. (1966). Serotypes and particle dimensions of tobacco rattle viruses from Europe and America. Virology 28, 610-620.

Inoue, H., Nakagawa, T. \& Morihara, K. (I963). Pseudomonas aeruginosa proteinase. II. Molecular weight and molecular dimension. Biochimica et biophysica acta 73, I25-I 3 I.

MAtsubara, H. \& Feder, J. (197I). Other bacterial, mold, and yeast proteases. In The Enzymes, 3rd edn., vol. 3, pp. 721-795. Edited by P. D. Boyer. New York and London: Academic Press.

MAYo, M. A. \& CoOPER, J. I. (1973). Partial degradation of the protein in tobacco rattle virus during storage. Journal of General Virology 18, 28 I-289.

Pérombelon, M. C. M. \& Lowe, W. (I97I). The effects of bile salts media and the age of inocula in quantitative studies of populations of Erwinia carotovora var. carotovora and E. carotovora var. atroseptica. Journal of Applied Bacteriology 34, 501-506.

SANDVIK, O. (1963). Studies on casein precipitating enzymes of aerobic and facultatively anaerobic bacteria. Veterinary College of Norway, Oslo.

Stanley, W. M. (1934). Chemical studies on the virus of tobacco mosaic. I. Some effects of trypsin. Phytopathology 24, $1055-1085$.

Winters, H. \& CORPE, W. A. (I97I). Polyacrylamide gel electrophoresis of exoenzymes produced by Pseudomonas fluorescens strain w. Canadian Journal of Microbiology 17, 24I-248. 